\title{
PYRENE MORPHOLOGY OF THREE SPECIES OF Byrsonima Rich. ex Kunth (Malpighiaceae) ${ }^{1}$
}

\author{
Cylles Zara dos Reis Barbosa ${ }^{2}$, Maria Silvia de Mendonça ${ }^{3}$ e Rodrigo Schütz Rodrigues ${ }^{4}$
}

\begin{abstract}
The species of the genus Byrsonima Rich. ex Kunth are of great medicinal and economic importance, but they are still poorly studied with respect to their propagules. This study describes, illustrates and comparse morphological aspects of the pyrenes of Byrsonima crassifolia (L.) Kunth, Byrsonima verbascifolia (L.) DC. and Byrsonima coccolobifolia Kunth occurring in areas of savannah of Boa Vista, Roraima. The pyrenes are globoid, obovoid to ovoid, with endocarp dark brown in color, with a corrugated and reticulate surface and corneous consistency. They possess distinctly septate locules with or without seeds, the outer wall of which are dark brown in color with corneous consistency and thin black inner walls also with corneous consistency. The number of locules and seeds per pyrene among the species varies. The seeds are exalbuminous, globoid, obovoid to ovoid, with a thin, smooth integument and are light-brown in color. They have radicular lobes and hypostasis. The embryo is continuous and axial with cylindrical spirally rolled cotyledons. The diameter of pyrenes of Byrsonima crassifolia is greater than in the other two species. The pyrenes of $B$. coccolobifolia are longer and heavier, while those of $B$. verbascifolia are lighter and the seeds have greater lengths, widths and thickness compared to the other two species studied. The three species have similar morphologies, differing in the size and weight of pyrenes and seeds.
\end{abstract}

Keywords: Diaspore; Plant morphology; Murici.

\section{MORFOLOGIA DE PIRÊNIO DE TRÊS ESPÉCIES DE Byrsonima Rich. ex Kunth (Malpighiaceae)}

\begin{abstract}
RESUMO - As espécies de Byrsonima Rich. ex Kunth são de grande importância medicinal e econômica, mas ainda são pouco estudadas quanto à unidade de propagação. Este estudo teve como objetivo descrever, ilustrar e comparar aspectos morfológicos dos pirênios de Byrsonima crassifolia (L.) Kunth, Byrsonima verbascifolia (L.) DC. e Byrsonima coccolobifolia Kunth ocorrentes em áreas de savana de Boa Vista, Roraima. Os pirênios são globoide, obovoide a ovoide, com endocarpo de coloração marrom-escuro, superficie rugosa e reticulada, e consistência córnea. Possuem lóculos distintos septados com ou sem sementes, cujas paredes externas são de coloração marrom-escuro, grossa e de consistência córnea e as paredes internas são de cor preta, fina e de consistência córnea. Foi observada a variação do número de lóculos e sementes por pirênio entre as espécies. As sementes são exalbuminosas, globoide, obovoide a ovoide, com tegumento de coloração marromclaro, delgado e liso. Apresentam lobo radicular e hipóstase. O embrião é contínuo e axial, com cotilédones cilíndricos e enrolados em espiral. Os pirênios de B. crassifolia apresentam diâmetro superior aos das duas outras espécies. Por sua vez, os de B. coccolobifolia possuem maior comprimento e peso, enquanto que os de B. verbascifolia apresentam menor peso e as sementes com maior comprimento, largura e espessura em relação às outras duas espécies estudadas. As três espécies apresentam padrão morfológico semelhante entre si, diferenciando-se na dimensão e peso dos pirênios e sementes.
\end{abstract}

Palavras-chave: Diásporo; Morfologia vegetal; Murici.

\footnotetext{
${ }^{1}$ Recebido em 11.08.2014 aceito para publicação em 09.06.2015.

${ }^{2}$ Universidade Federal do Amazonas, Programa de Pós-Graduação em Agronomia Tropical, Manaus, AM - Brasil. E-mail: <zarabarbosa@bol.com.br>.

${ }^{3}$ Universidade Federal do Amazonas, Departamento de Ciências Fundamentais e Desenvolvimento Agrícola, Manaus, AM

- Brasil. E-mail:<msilvia@ufam.edu.br>.

${ }^{4}$ Universidade Federal de Roraima, Centro de Estudos da Biodiversidade, Campus do Paricarana, Boa Vista, RR - Brasil. E-mail: <rodrigo.schutz@ufrr.br>.
} 


\section{INTRODUCTION}

Malpighiaceae comprises 44 genera and 528 species distributed in all phytogeographic areas of Brazil (GIULIETTI et al., 2005; MAMEDE, 2013). Byrsonima Rich. ex Kunth is the largest genus in the family with 130 exclusively neotropical species (DAVIS; ANDERSON, 2010). Ninety three species occur in Brazil, of which 49 species are concentrated in Northern Region, which has the largest in number of species (MAMEDE, 2013).

In Roraima, some Byrsonima species are fundamental elements of the structure of many savanna communities, especially B. crassifolia (L.) Kunth, B. verbascifolia (L.) DC. and B. coccolobifolia Kunth (MIRANDA et al., 2003; BARBOSA; FEARNSIDE, 2004). Seventeen percent of Roraima is occupied by savannas, locally known as "Lavrado" (BARBOSA, 1997). These represent the largest continuous area of savannas of the Amazon Biome, with about $42,706 \mathrm{~km}^{2}$, forming the "Rio BrancoRupununi" landscape complex (BARBOSA et al., 2007; BARBOSA; CAMPOS, 2011). These species, popularly known as "murici", are extensively used in popular medicine, especially in the treatment of diarrhea and skin infections (AMARQUAYE et al., 1994; MENDANHA et al., 2010). Furthermore, the sweet and juicy fruits are used in the preparation of juices, soft drinks and ice creams (GUSMÃO et al., 2006; ARAÚJO et al., 2009). Finally, some species have great potential as ornamental and forage plants, serving for restoration of degraded areas (VALLILO, 2007).

Despite their recognized potential in economy and medicine, few Byrsonima species have been studied with respect to the structure of their propagules (SOUTO; OLIVEIRA, 2005). The propagule of these species is a pyrene (BARROSO et al., 1999), popularly called core, which consists of the endocarp and the seeds (CARVALHO et al., 2006).

The morphologies of propagules is extremely important in the identification of species for ecological and systematic studies, as they show little phenotypic plasticity (MARTINS; OLIVEIRA 2001; BRAZ et al., 2009; LOPES et al., 2010). Knowledge of morphological aspects of seed coats is fundamental to management, paleobotany, archeology and plant pathology, and also to help understand the germination process, vigor, storage, quality tests, viability and propagation of the species (MATHEUS; LOPES, 2007).
No detailed morphological studies of the pyrenes and seeds of the species of Byrsonima of Roraima were found in a survey of the literature. In this study we describe, illustrate and compare morphological aspects of the pyrenes of B. crassifolia, B. verbascifolia and B. coccolobifolia from savanna areas of Boa Vista, Roraima.

\section{MATERIALAND METHODS}

The observations and descriptions were made on pyrenes and seeds of Byrsonima crassifolia, $B$. verbascifolia and $B$. coccolobifolia from ripe fruits collected manually from 12 individuals, between April and July 2012, in the Água Boa Experimental Field, belonging to Embrapa/Roraima, located $36 \mathrm{~km}$ south of the city of Boa Vista, the capital of the state of Roraima

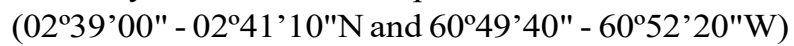
(RODRIGUES et al., 2000).

For each species, voucher specimens was deposited in the Herbarium of the Integrated Museum of Roraima (MIRR): B. crassifolia - BRASIL, Roraima, Boa Vista, Campo Experimental Água Boa of Embrapa Roraima, 03/IV/2012, fl., C.Z.R. Barbosa s.n. (MIRR 9551), B. verbascifolia - BRASIL, Roraima, Boa Vista, Campo Experimental Água Boa of Embrapa Roraima, 03/IV/ 2012, fl., C.Z.R. Barbosa s.n. (MIRR 9553) and $B$. coccolobifolia - BRASIL, Roraima, Boa Vista, Campo Experimental Água Boa of Embrapa Roraima, 03/IV/ 2012, fl., C.Z.R. Barbosa s.n. (MIRR 9550).

After collection, the fruits were kept in polyethylene bags for three to five days at room temperature of 24 $\pm 2^{\circ} \mathrm{C}$ and relative humidity of $60 \pm 5 \%$ to complete maturation and make the removal of the mesocarp easier (MURAKAMI et al., 2011). The mesocarp removal was carried out by rubbing it on the screen of a plastic sieve under a continuous flow of running water until the pyrenes were completely devoid of mesocarp residues (CARVALHO; NASCIMENTO, 2008; BIZÃO et al., 2011; MURAKAMI et al., 2011; NASCIMENTO et al., 2011). After removing the mesocarp and excess water, the pyrenes were placed to dry on paper towel (CARVALHO; NASCIMENTO, 2008) for three days at room temperature of $24 \pm 2{ }^{\circ} \mathrm{C}$ and relative humidity $60 \pm 5 \%$ of the Seed Analysis Laboratory of Embrapa/Roraima and then placed in sealed polyethylene bags and stored for further morphological assessments.

The morphology of the pyrenes was described and illustrated from 100 examples of each species. 
Externally, the shape, color, surface, texture, consistency, length, diameter and weight of the pyrenes were recorded. Internally, the number of loci and seeds, their color, surface, texture and consistency were recorded. The moisture content and the weight of a thousand pyrenes were made according to Brasil (2009). The internal and external morphology of the seeds was described and illustrated from 50 examples of each species. Internally, the type and shape, color, surface, texture, and seed coat consistency, presence of radicular lobe and hypostasis, hilum position, micropyle position, length, breadth, thickness and weight were recorded. Internally, the shape and position of the embryo, type and color of the cotyledon, color and position of the hypocotylradicle axis were recorded. The descriptions and illustrations of the interiors of the pyrenes and seeds were from samples soaked in water for 24 hours and cut in lengthwise and crosswise sections using a simple blade. The length and diameter of the pyrenes and the length, breadth and thickness of seeds were measured with the aid of a digital caliper with precision of 0.01 $\mathrm{mm}$ and the weight with the aid of a precision balance of $0.001 \mathrm{~g}$. The length was measured between the basal and apical tips and the diameter, breadth and thickness at the middle. The seeds were extracted from the pyrenes by compressing them at the base towards the apex with the aid of clamp pliers fitted with conical steel bases, which is an efficient, practical and novel method for these species. Those which were malformed or had mechanical injuries were discarded. The maximum, mean, and minimum values, and the variance, standard deviation and coefficient of variation were calculated for the length, width, thickness and weight of the seeds and also for the length, diameter, weight, moisture content of the pyrenes and weight of a thousand pyrenes. The number of locules and seeds per pyrene was estimated from the frequency distribution.

The morphological terminology is based on Corner (1976), Barroso et al. (1999), Souto and Oliveira (2005) and Camargo et al. (2008). Morphological illustrations of pyrenes and seeds were made visually and from photographs taken with an Opton stereomicroscope with a camera clara, coupled to a Power Samsung MV800 digital camera.

\section{RESULTS}

The pyrenes of $B$. coccolobifolia, $B$. crassifolia and $B$. verbascifolia vary from globoid, obovoid to ovoid and have dark, brown-colored, opaque endocarp, with a rough and reticulate surface, harsh texture and corneous consistency, with a truncated and invaginated base and an acute apex (Figure 1A-B; Figure 1E-F; Figure 1I-J).

The three species of Byrsonima have varying size, moisture content and weight of a thousand pyrenes (Table 1). B. coccolobifolia had the longest pyrenes (4.67-6.86 mm) and greatest weight (0.04-0.90 g); $B$. crassifolia had the greatest diameter (4.40-6.94 $\mathrm{mm}$ ) and $B$. verbascifolia had the lowest weight $(0.03-0.09 \mathrm{~g})$. The pyrenes of $B$. crassifolia $(11.22-11.32 \%)$ and $B$. verbascifolia (11.09-11.19\%) had the highest moisture content, while those of $B$. coccolobifolia and $B$. crassifolia, the greatest values of weight of one thousand pryrenes (8.101-8.363 $\mathrm{g}$ and 7.124-7.710 g, respectively).

The pyrenes of the three species possess distinct septate locules, with or without seeds, the outer walls are dark-brown in color, opaque and thick, with a smooth surface, rough texture and corneous consistency and their inner walls are black, bright and thin, with a smooth, waxy surface and corneous consistency. The number of locules and seeds per pyrene ranged amongst the species studied (Figure 2 and Figure 3). B. verbascifolia had the highest number of pyrenes with three locules (78.7\%) and B. coccolobifolia highest number of pyrenes with two locules (43.3\%). B. coccolobifolia had the lowest number of pyrenes without zero or three seeds ( $17.5 \%$ and $0.8 \%$, respectively) and the highest number of pyrenes with one and two seeds (46.7\% and 35.0\%, respectively). It was still observed that the dimensions of the seeds on the inside of the pyrenes are variable in the three species.

The seeds of $B$. coccolobifolia, B. crassifolia and $B$. verbascifolia are exalbuminous, ranging from globoid, obovoid to ovoid with light-brown, thin, smooth, oily and membranous tegument. The three species of Byrsonima have a radicular lobe ranging from inconspicuous to exposed, in which lies the micropyle and the inconspicuous hilum and next to it, a more or less discrete, more pigmented area which corresponds to the hypostasis (Figure 1C; Figure 1G; Figure 1K). The size and weight of the seeds ranged amongst the

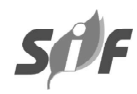

Revista Árvore, Viçosa-MG, v.39, n.5, p.831-839, 2015 

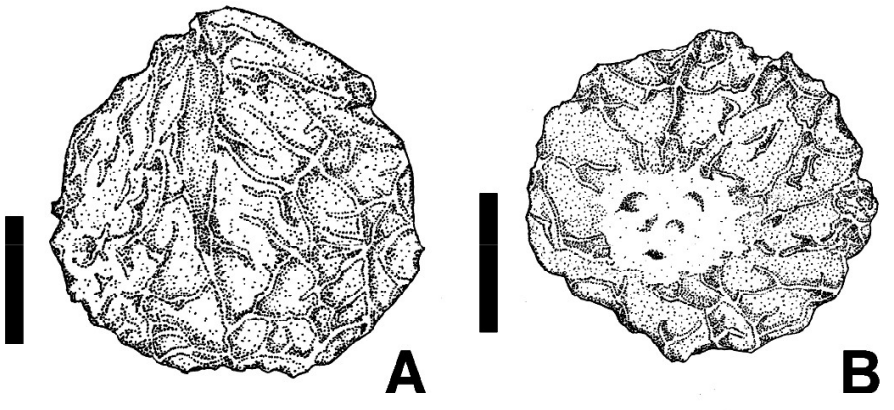

B

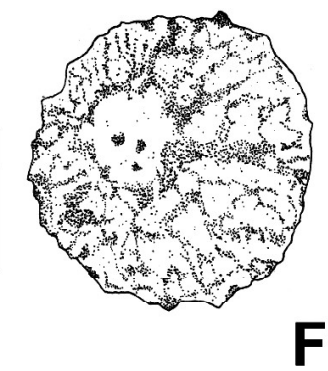

$\mathbf{E}$
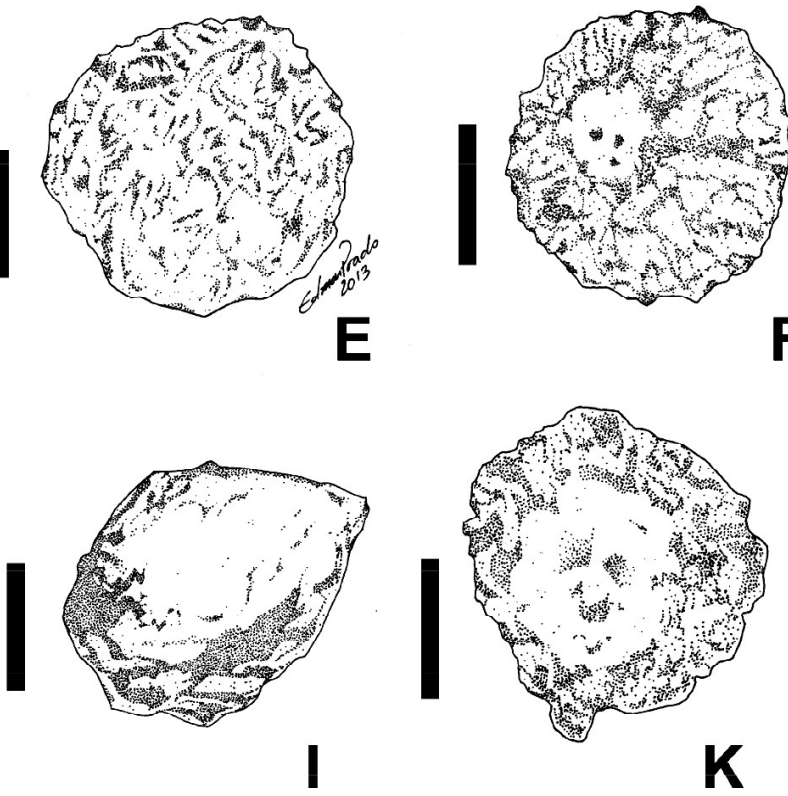
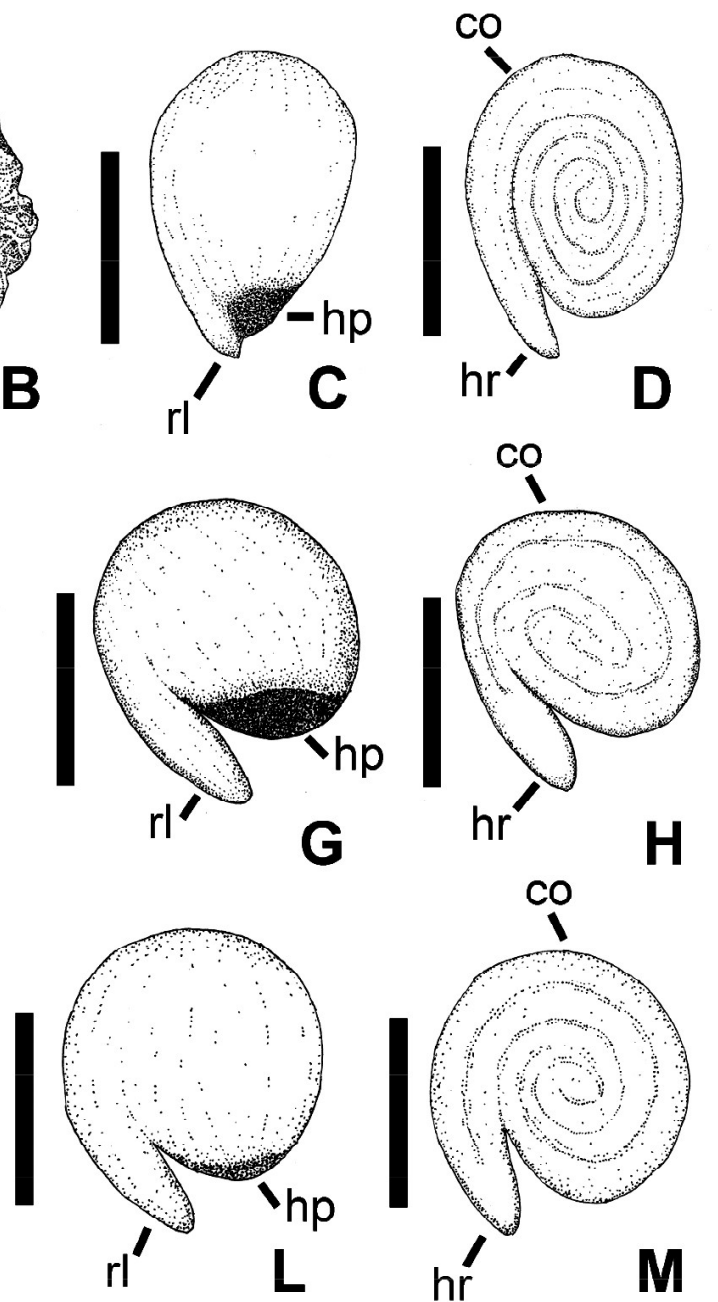

Figure 1 - Pyrenes and seeds of Byrsonima coccolobifolia, Byrsonima crassifolia and Byrsonima verbascifolia from savanna areas in Boa Vista, Roraima. A. Side view of pyrene of $B$. coccolobifolia. B. Truncated base of pyrene of $B$. coccolobifolia. C. Side view highlighting the radicular lobe and seed hypostasis of $B$. coccolobifolia. D. Embryo in longitudinal section of $B$. coccolobifolia. E. Side view of pyrene of $B$. crassifolia. F. Truncated base of pyrene of $B$. crassifolia. G. Side view highlighting the radicular lobe and seed hypostasis of $B$. crassifolia. H. Embryo in longitudinal section of $B$. crassifolia. I. Side view of pyrene of $B$. verbascifolia. J. Truncated base of pyrene of $B$. verbascifolia. K. Side view highlighting the radicular lobe and seed hypostasis of $B$. verbascifolia. L. Embryo in longitudinal section of $B$. verbascifolia.$(\mathrm{rl}=$ radicular lobe; $\mathrm{hp}=$ hypostasis; $\mathrm{co}=$ cotyledon; $\mathrm{hr}=$ hypocotylroot axis). Bars $=2 \mathrm{~mm}$.

Figura 1 - Pirênios e sementes de Byrsonima coccolobifolia, Byrsonima crassifolia e Byrsonima verbascifolia de áreas de savana de Boa Vista, Roraima. A. Vista lateral do pirênio de B. coccolobifolia. B. Vista da base truncada do pirênio de B. coccolobifolia. C. Vista lateral destacando o lobo radicular e a hipóstase da semente de $\boldsymbol{B}$. coccolobifolia. D. Embrião em secção longitudinal da semente de B. coccolobifolia. E. Vista lateral do pirênio de B. crassifolia. F. Vista da base truncada do pirênio de B. crassifolia. G. Vista lateral destacando o lobo radicular e a hipóstase da semente de B. crassifolia. H. Embrião em seç̧ão longitudinal da semente de B. crassifolia. I. Vista lateral do pirênio de B. verbascifolia. J. Vista da base truncada do pirênio de B. verbascifolia. K. Vista lateral destacando o lobo radicular e a hipóstase da semente de B. verbascifolia. L. Embrião em secção longitudinal da semente de B. verbascifolia. ( $r l=$ lobo radicular; $h p=$ hipóstase; co = cotilédone; $h r=$ eixo hipocótiloradicular). Barras $=2 \mathrm{~mm}$.

Revista Árvore, Viçosa-MG, v.39, n.5, p.831-839, 2015 
Table 1 - Length, diameter, weight, moisture content and weight of a thousand pyrenes of Byrsonima crassifolia, B. verbascifolia and $B$. coccolobifolia from savanna areas in Boa Vista, Roraima.

Tabela 1 - Comprimento, diâmetro, peso, grau de umidade e peso de mil pirênios de Byrsonima crassifolia, B. verbascifolia e B. coccolobifolia de áreas de savana de Boa Vista, Roraima.

\begin{tabular}{|c|c|c|c|c|c|c|}
\hline Species & Maximum & Average & Minimum & $\mathrm{S}^{1}$ & $\mathrm{DP}^{2}$ & $\mathrm{CV}(\%)^{3}$ \\
\hline \multicolumn{7}{|c|}{ Pyrene lenght (mm) } \\
\hline B. crassifolia & 6.38 & 5.263 & 4.09 & 0.2028 & 0.4504 & 8.56 \\
\hline B. verbascifolia & 6.66 & 5.233 & 2.02 & 0.4034 & 0.6352 & 12.14 \\
\hline B. coccolobifolia & 6.86 & 5.555 & 4.67 & 0.2395 & 0.4893 & 8.81 \\
\hline \multicolumn{7}{|c|}{ Pyrene diameter (mm) } \\
\hline B. crassifolia & 6.94 & 5.564 & 4.40 & 0.2487 & 0.4987 & 8.96 \\
\hline B. verbascifolia & 6.00 & 5.172 & 4.39 & 0.1318 & 0.3631 & 7.02 \\
\hline B. coccolobifolia & 6.78 & 5.642 & 4.32 & 0.3258 & 0.5708 & 10.12 \\
\hline \multicolumn{7}{|c|}{ Pyrene weight (g) } \\
\hline B. crassifolia & 0.76 & 0.089 & 0.03 & 0.0063 & 0.0797 & 89.14 \\
\hline B. verbascifolia & 0.09 & 0.054 & 0.03 & 0.0001 & 0.0113 & 20.99 \\
\hline B. coccolobifolia & 0.90 & 0.096 & 0.04 & 0.0112 & 0.1057 & 109.95 \\
\hline \multicolumn{7}{|c|}{ Moisture content of pyrene $(\%)$} \\
\hline B. crassifolia & 11.32 & 11.27 & 11.22 & 0.0050 & 0.0707 & 0.62 \\
\hline B. verbascifolia & 11.19 & 11.14 & 11.09 & 0.0050 & 0.0707 & 0.63 \\
\hline B. coccolobifolia & 10.86 & 10.83 & 10.79 & 0.0025 & 0.0494 & 0.45 \\
\hline \multicolumn{7}{|c|}{ Weight of a thousand pyrenes (g) } \\
\hline B. crassifolia & 7.710 & 7.353 & 7.124 & 0.0488 & 0.2208 & 3.00 \\
\hline B. verbascifolia & 4.981 & 4.806 & 4.531 & 0.0415 & 0.2036 & 4.24 \\
\hline B. coccolobifolia & 8.363 & 8.205 & 8.101 & 0.0085 & 0.0925 & 1.13 \\
\hline
\end{tabular}

${ }^{1} \mathrm{~S}=$ Variance $;{ }^{2} \mathrm{DP}=$ Standard deviation; ${ }^{3} \mathrm{CV}=$ Coefficient of variation $(\%)$.

species (Table 2). B. verbascifolia had seeds with greater length, breadth and thickness (2.53-4.08 x 2.28-3.51 $\mathrm{x} 1.45-2.38 \mathrm{~mm}$ ) and B. coccolobifolia with greatest weight ranging from 0.005 to $0.013 \mathrm{~g}$ (Table 2).

The embryos of $B$. coccolobifolia, B. crassifolia and $B$. verbascifolia are continuous and axial with white, circinate cotyledons; the hypocotyl-radicle axis is white and continuous to the two adjacent cotyledons and rolled spirally on itself(Fig 1D; Fig. 1H; Fig. 1L).

\section{DISCUSSION}

The pyrenes of the three species have homogeneity of color and form, however, variations in color and shape have been documented for some species of Byrsonima. According to the classification of Barroso et al. (1999), the pyrenes of Byrsonima species are angular. Camargo et al. (2008) reported that the pyrene of $B$. chrysophylla Kunth is globe-shaped, whitish brown and opaque, rough and reticulate, with firm consistency and a truncated to invaginated base with a slightly pointed apex. Among in Açu clone of $B$. crassifolia, Carvalho and Nascimento (2008) observed that the pyrenes were oval, brown, hard, reticulated and pointed at the apical end and depressed in the basal portion. Although observations vary as to the color and shape of pyrenes, it is noteworthy that the remaining characters of the general morphology described for the species mentioned above reflect the pattern found in B. crassifolia, B. verbascifolia and B. coccolobifolia.

The length and diameter of the pyrenes in the present study are, in general, larger when compared to the pyrenes of the Açu clone of B. crassifolia (CARVALHO; NASCIMENTO, 2008) and to those of B. crassa Nied. (SILVÉRIO; FERNANDES-BULHÃO, 2009) and smaller than those of $B$. verbascifolia (L.) DC. and B. orbignyana A. Juss. (SILVÉRIO; FERNANDES-BULHÃO, 2009). The pyrenes of $B$. coccolobifolia are lighter than those of the Açu clone of $B$. crassifolia (CARVALHO et al., 2006; CARVALHO; NASCIMENTO, 2008). It was also found that the pyrenes of $B$. coccolobifolia are heavier than those of B. crassifolia and B. verbascifolia. But, the pyrenes of $B$. verbascifolia here studied are heavier than those examined by Silvério and Fernandes-Bulhão (2009). It is noteworthy that these morphological data are relevant in the identification of species of the same 


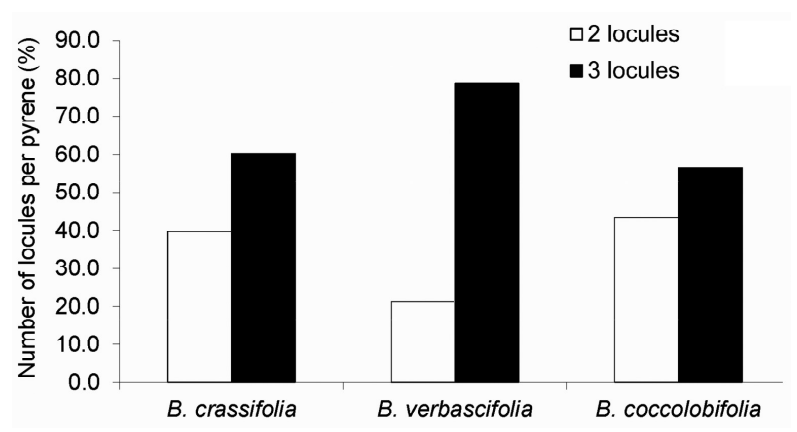

Figure 2 - Number of locules per pyrene of Byrsonima crassifolia, $B$. verbascifolia and $B$. coccolobifolia from savanna areas in Boa Vista, Roraima.

Figura 2 - Número de lóculos por pirênio de Byrsonima crassifolia, B. verbascifolia e B. coccolobifolia de áreas de savana de Boa Vista, Roraima.

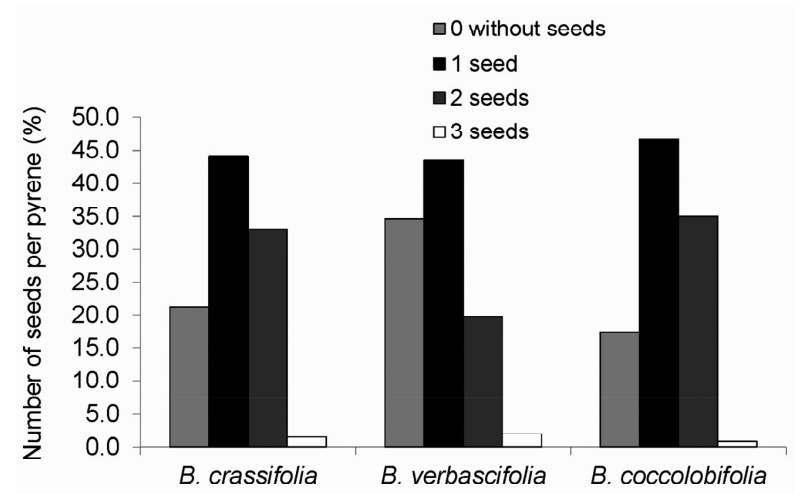

Figure 3 - Number of seeds per pyrene of Byrsonima crassifolia, $B$. verbascifolia and $B$. coccolobifolia from savanna areas in Boa Vista, Roraima.

Figura 3 - Número de sementes por pirênio de Byrsonima crassifolia, B. verbascifolia e B. coccolobifolia de áreas de savana de Boa Vista, Roraima.

genus of different biomes. Lopes et al. (2010) found that the seeds of Plathymenia foliolosa of Atlantic Forest patches are longer and thicher than those of $P$. reticulata in cerrado.

The pyrenes of B. crassifolia and B. verbascifolia showed higher values of moisture content than those of B. coccolobifolia ( 10.79 to $10.86 \%$ ). The determination of the moisture content of the seeds of the species is important for their storage. According to Marcos Filho (2005) seeds stored with a moisture content of between $10-13 \%$ have no biochemical reactions that compromise their germination, furthermore, a low moisture range reduces the rate of deterioration.
Byrsonima coccolobifolia and B. crassifolia were heavier thousand pyrenes (8.101 to 8.363 and 7.710 to $7.124 \mathrm{~g}$ ), such information is important for calculation sowing density. Araújo et al. (2009), studying $B$. verbascifolia, recorded a weight of 1000 pyrenes, 136.30 $\mathrm{g}$, higher than in the present study, which can be attributed, among other factors, to the environmental and genetic diversity of the species studied that have not yet been domesticated.

Some of the features of the locules of $B$. crassifolia, $B$. verbascifolia and $B$. coccolobifolia are similar to those described by Carvalho and Nascimento (2008) for the Açu clone of B. crassifolia. They describe seminiferous locules with the internal wall much thinner than the external. According to Barroso et al. (1999), pyrenes of Byrsonima are crested and trilocular. This is seen in B. verbascifolia and $B$. crassifolia, which had a higher percentage of pyrenes with three locules (60.3 and $78.7 \%$, respectively), while $B$. coccolobifolia had the highest number of pyrenes with two locules (43.3\%). $B$. coccolobifolia had more seeds per locule than the other species, with the highest number of pyrenes with one seed (more than $45 \%$ ) and with two seeds $(35 \%)$. B. verbascifolia had the highest number of pyrenes with three seeds, $2.0 \%$ relative to the other two species. Furthermore, B. verbascifolia had the lowest number of pyrene with two seeds (less than $20 \%$ ), which is less than than those observed by Silverio and Fernandes-Bulhão (2009), who recorded $32 \%$ of pyrenes with two seeds. B. crassifolia had the highest frequency of pyrenes with one $(44.22 \%)$ and two (33.1\%) seeds relative to $B$. verbascifolia. These results differed from those reported by Carvalho and Nascimento (2008), who observed for the Açu clone of $B$. crassifolia, the highest frequency of pyrenes contained two seeds, however, the ratio of pyrenes with no seeds was also small, as was also observed in this study.

B. intermedia A. Juss. has exalbuminous, obovate seeds, with radicular lobes and hypostasis (SOUTO; OLIVEIRA, 2005), these were also observed in the seeds of three species of Byrsonima studied, except that seed shape ranged from globoid, obovoid to ovoid. The presence of a thin seed coat with corneous consistency on removal from the pyrene is also common in Malpighiaceae (CORNER, 1976; CARVALHO; NASCIMENTO, 2008). Despite the constancy of traits 
Table 2 - Length, width, thickness and weight of the seeds of Byrsonima crassifolia, Byrsonima verbascifolia and Byrsonima coccolobifolia from savanna areas in Boa Vista, Roraima.

Tabela 2 - Comprimento, largura, espessura e peso das sementes de Byrsonima crassifolia, B. verbascifolia e B. coccolobifolia de áreas de savana de Boa Vista, Roraima.

\begin{tabular}{|c|c|c|c|c|c|c|}
\hline Species & Maximum & Average & Minimum & $\mathrm{S}^{1}$ & $\mathrm{DP}^{2}$ & $\mathrm{CV}(\%)^{3}$ \\
\hline \multicolumn{7}{|c|}{ Seed length $(\mathrm{mm})$} \\
\hline B. crassifolia & 3.83 & 2.791 & 2.22 & 0.0870 & 0.2950 & 10.57 \\
\hline B. verbascifolia & 4.08 & 3.485 & 2.53 & 0.1098 & 0.3314 & 9.51 \\
\hline B. coccolobifolia & 3.85 & 2.828 & 2.23 & 0.1184 & 0.3441 & 12.17 \\
\hline \multicolumn{7}{|c|}{ Seed width $(\mathrm{mm})$} \\
\hline B. crassifolia & 3.14 & 2.593 & 2.10 & 0.0679 & 0.2606 & 10.05 \\
\hline B. verbascifolia & 3.51 & 2.862 & 2.28 & 0.0568 & 0.2383 & 8.33 \\
\hline B. coccolobifolia & 3.23 & 2.589 & 1.96 & 0.0929 & 0.3048 & 11.77 \\
\hline \multicolumn{7}{|c|}{ Seed thickness (mm) } \\
\hline B. crassifolia & 2.05 & 1.485 & 1.05 & 0.0502 & 0.2240 & 15.09 \\
\hline B. verbascifolia & 2.38 & 1.815 & 1.45 & 0.0516 & 0.2272 & 12.52 \\
\hline B. coccolobifolia & 2.24 & 1.693 & 1.24 & 0.0368 & 0.1920 & 11.34 \\
\hline \multicolumn{7}{|c|}{ Seed weight $(\mathrm{g})$} \\
\hline B. crassifolia & 0.010 & 0.006 & 0.004 & 4.4636 & 0.0021 & 30.89 \\
\hline B. verbascifolia & 0.010 & 0.007 & 0.004 & 2.1832 & 0.0015 & 21.05 \\
\hline B. coccolobifolia & 0.013 & 0.009 & 0.005 & 3.4893 & 0.0019 & 20.71 \\
\hline
\end{tabular}

${ }^{1} \mathrm{~S}=$ Variance $;{ }^{2} \mathrm{DP}=$ Standard deviation $;{ }^{3} \mathrm{CV}=$ Coefficient of variation $(\%)$.

among the seeds of these species, variation in seed coat color stands out, being light brown in B. crassifolia, $B$. verbascifolia and $B$. coccolobifolia. Souto and Oliveira (2005) studying the species $B$. intermedia, reported that the seed coats are blackened, while Carvalho and Nascimento (2008) report the seed coat color of the Açú clone of B. crassifolia as cream. Camargo et al. (2008) record the seeds of $B$. chysophylla as light yellow to brown.

Seeds of $B$. verbascifolia are bigger (2.53 to 4.08 $\mathrm{x} 2.28$ to $3.51 \times 1.45$ to $2.38 \mathrm{~mm}$ ) compared to the other two species. These dimensions are similar to those observed by Souto and Oliveira (2005), which were 0.22 to $0.43 \times 0.21$ to $0.35 \times 0.13$ to $0.24 \mathrm{~cm}$ for seeds of $B$. intermedia. However, seeds of $B$. coccolobifolia are heavier $(0.005$ to $0.013 \mathrm{~g})$ than those of $B$. crassifolia and $B$. verbascifolia which weighed 0.004 to $0.010 \mathrm{~g}$, similar to those observed by Carvalho and Nascimento (2008), with a weight of 0.003 to $0.037 \mathrm{~g}$ in the Açu clone of B. crassifolia.

A typical characteristic of the species of Byrsonima is the continuous and axial embryo with circinate cotyledons (BARROSO et al., 1999; SOUTO; OLIVEIRA, 2005; CAMARGO et al., 2008), as observed in $B$. crassifolia, $B$. verbascifolia and $B$. coccolobifolia.

\section{CONCLUSION}

The pyrenes and seeds of the three species studied have a similar morphology. However, the pyrenes of $B$. crassifolia have a greater diameter than those of the two other species. The pyrenes of $B$. coccolobifolia are longer and heavier, while those of $B$. verbascifolia are lighter, and the seeds are longer, wider and thicker relative to the other two species. These traits of pyrenes and seeds allow identification of the three species of Byrsonima of Roraima's savannah areas. In addition, the results obtained in this work represent the first report of the morphology of pyrenes and seeds for $B$. crassifolia, B. verbascifolia and $B$. coccolobifolia and can serve to guide future studies on ecology, taxonomy, seed technology and breeding of these species which have yet to be domesticated.

\section{ACKNOWLEDGMENTS}

To CAPES (Coordination of Improvement of Higher Education Personnel), a government agency, for the scholarship granted to the first author at the Postgraduate Program in Tropical Agriculture at UFAM (Federal University of Amazonas); to the Center for Biodiversity Studies at UFRR (Federal University of Roraima) for logistical assistance; to Dr. Reinaldo Barbosa Imbrozio at INPA (National Institute for Amazonian 
Research) for his help in identifying species in field; to MSc. Edmar da Silva Prado for illustrations; to Dr. Oscar José Smiderle (Embrapa Roraima); and to Larisse Souza Campos Oliva, agronomist, for her assistance at the Seed Analysis Laboratory of Embrapa Roraima.

\section{REFERENCES}

AMARQUAYE, A.; CHE, C.T.; BEJAR, E.; MALONE, M.H.; FONG, H.H.S. A new glycolipid from Byrsonima crassifolia. Planta Medica, v. 60, n.1, p.85-86, 1994.

\section{ARAÚJO, R.R.; SANTOS, E.D.; LEMOS, E.E.P.} Caracterização biométrica de frutos e sementes de genótipos de murici (Byrsonima verbascifolia (L.) Rich.) do tabuleiro costeiro de Alagoas, Revista Caatinga, v.22, n.3, p.224-228, 2009.

BARBOSA, R.I. Distribuição das chuvas em Roraima. In: BARBOSA, R.I.; FERREIRA, E. J.G.; CAstellón, E.G. Homem, ambiente e ecologia no estado de Roraima. Manaus: INPA, 1997. 325-335p.

BARBOSA, R.I.; FEARNSIDE, P.M. Wood density of trees in open savanas of the Brazilian Amazon. Forest Ecology and management, v.199, n. 1, p.115-123, 2004.

BARBOSA, R.I.; CAMPOS, C. Detection and geographical distribution of clearing areas in the savannas ('lavrado') of Roraima using Google Earth web tool. Journal of Geography and Regional Planning, v.4, n.3, p.122-136, 2011.

BARBOSA, R.I.; CAMPOS, C.; PINTO, F.; FEARNSIDE, P.M. The "Lavrados" of Roraima: Biodiversity and Conservation of Brazil's Amazonian Savannas. Functional Ecosystems and Communities, v.1, n.1, p.29-41, 2007.

BARROSO, G.M.; MORIM, M.P.; PEIXOTO, A.L.; ICHASO, C.L.F. Frutos e sementes: morfologia aplicada à sistemática de dicotiledôneas. Viçosa, MG: Universidade Federal de Viçosa, 1999. 443p.

BIZÃO, N.; MURAKAMI, D.M.; COSTA, A.S. Avaliação dos efeitos da lixiviação, dano mecânico no endocarpo e de giberelina na emergência de Byrsonima cydoniifolia A.Juss. em dois substratos. Revista de Ciências

Agro-Ambientais, v.9, n.1, p.121-129, 2011.

BRAZ, M.S.S.; SOUZA, V.C.; ANDRADE, L.A.; BRUNO, R.L.A.; OLIVEIRA, L.S.B.; SILVA, J.M. Caracterização morfológica de frutos, sementes e plântulas de jacarandá-da-bahia (Dalbergia nigra (Vell.) Fr. All. ex. Benth.) LeguminosaePapilonoideae. Revista Brasileira de Ciências Agrárias, v.4, n.1, p.67-71, 2009.

BRASIL. Ministério da Agricultura, Pecuária e Abastecimento. Regras para análise de sementes. Brasília: Secretária de Defesa Agropecuária, 2009. 399p.

CARMARGO, J.L.C.; FERRAZ, I.D.K.; MESQUITA, M.R.; SANTOS, B.A.; BRUM, H.D. Guia de propágulos e plântulas da Amazônia. Manaus: Instituto Nacional de Pesquisas da Amazônia, 2008. 168p.

CARVALHO, J.E.U.; NASCIMENTO, W.M.O Caracterização dos pirênios e métodos para acelerar a germinação de sementes de muruci do clone Açu. Revista Brasileira de Fruticultura, v.30, n.3, p.775-781, 2008.

CARVALHO, J.E.U.; NASCIMENTO, W.M.O.; MÜlleR, C.H. Propagação do

Murucizeiro. Belém: Embrapa Amazônia Oriental, 2006. (Documentos, 261).

CORNER, E.J.H. The seeds of the Dicotyledons. London: Cambridge University Press, 1976. 311p.

DAVIS, C.C.; ANDERSON, W.R. A complete generic phylogeny of Malpighiaceae inferred from nucleotide sequence data and morphology. American Journal of Botany, v.97, n.12, p.2031-2048, 2010.

GIULIETTI, A.M.; HARLEY, R.M.; QUEIROZ, L.P.; WANDERLEY, M.G.; BER, C.V.D. Biodiversidade e conservação das plantas no Brasil.

Megadiversidade, v.1, n.1, p.52-61, 2005

GUSMÃO, E.; VIEIRA, F.A.; JÚNIOR FONSECA, E.M. Biometria de frutos e endocarpos de murici (Byrsonima verbascifolia Rich. ex A. Juss.). Cerne, v. 12, n.1, p.84-91, 2006. 
LOPES, R.M.F.; FREITAS, V.L.O.; FILHO, J.P.L. Biometria de frutos e sementes e germinação de Plathymenia reticulata Benth e Plathymenia foliolosa Benth. (Fabaceae-Mimosoideae). Revista Árvore, v.34, n.5, p.797-805, 2010.

MAMEDE, M.C.H. Byrsonima in Lista de Espécies da Flora do Brasil. 2013. Disponível em: http://reflora.jbrj.gov.br/jabot/ floradobrasil/?id=FB8827. Acesso em: 20 abr. 2013.

MARCOS FILHO, J. Fisiologia de sementes de plantas cultivadas. Piracicaba: FEALQ. 2005. 495p.

MARTINS, M.A.G.; OLIVEIRA, D.M.T.

Morfoanatomia e ontogênese do fruto e da semente de Tipuana tipu (Benth.) O. Kuntze (Fabaceae: Faboideae). Revista Brasileira de Botânica, v.24, n.1, p.109-121, 2001.

MATHEUS, M.T.; LOPES, J.C. Morfologia de frutos, sementes e plântulas e germinação de sementes de Erythrina variegata L. Revista Brasileira de Sementes, v.29, n.3, p.08-17, 2007.

MENDANHA, D.M.; FERREIRA, H.D.;FELÍCIO, L.P.; SILVA E.M.; PEREIRA, D.G.; NUMES, W.B.; CARVALHO, S. Modulatory effect of Byrsonima verbascifolia (Malpighiaceae) against damage induced by doxorubicin in somatic cells of Drosophila melanogaster. Genetics and Molecular Research, v.9, n.1, p.69-77, 2010.

MIRANDA, I.S., ABSY, M.L., REBELO, G.H. Community structure of woody plants of Roraima savannahs, Brazil. Plant Ecology, v. 164, n.1, p.109-123, 2003.

MURAKAMI, D.M.; BIZÃO, N.; VIEIRA, R.D. Quebra de dormência de semente de murici.

Revista Brasileira de Fruticultura, v.33, n.4, p.1257-1265, 2011.
NASCIMENTO, I.L.; LEAL, C.C.P.; NOGUEIRA, N.W.; MEDEIROS, A.K.P.; CÂMARA, F.M.M. Uso de metodologias variadas na quebra de dormência tegumentar de sementes de murici. Revista Verde, v.6, n.3, p.226-230, 2011.

OLIVEIRA, M.E.B.; GUERRA, N.B.; MAIA, A.H.N.; ALVES, R.E.; XAVIER, D.S.; MATOS, N.M.S. Caracterização física de frutos do pequizeiro nativos da chapada do Araripe-CE. Revista Brasileira de Fruticultura, v.31, n.4, p.1196-1201, 2009.

RODRIGUES,T.E.; GAMA, J.R.N.F.; RÊGO, R.S.; LIMA, A.A.C.; SILVA, J.M.L.; BARRETO, W.O. Caracterização e classificação dos solos do Campo Experimental de Água Boa - Embrapa Roraima, Boa Vista (RR). Belém: Embrapa Amazônia Oriental, 2000. (Documentos, 54).

SILVÉRIO, D.V.; FERNANDES-BULHÂO, C. Fenologia reprodutiva e biometria de frutos e sementes de três espécies de Byrsonima Rich. ex Kunth (Malpighiaceae) no Parque do Bacaba, Nova Xavantina - Mato Grosso. Revista de Biologia Neotropical, v.6, n.1, p.55-73, 2009.

SOUTO, L.S.; OLIVEIRA, D.M.T. Morfoanatomia e ontogênese do fruto e semente de Byrsonima intermedia A. Juss. (Malpighiaceae). Revista Brasileira de Botânica, v.28, n.4, p.697712, 2005.

VALLILO, M.I.; PASTORE, J.A.; ESTON, M.R.; GARBELOTTI, M.L; OLIVEIRA, E.

Caracterização química e valor nutricional dos frutos de Byrsonima myricifolia Griseb (Malpighiaceae) - alimento de aves silvestres. Revista do Instituto Florestal, v. 19, n.1, p.39-45, 2007. 